expenditure on space research by the Council for Scientific and Industrial Research is unlikely to be excessive, unless a considerable change were made in the allocation of its resources between the different stations. Allowing for grants for promising researches in this field which the Council is making in collaboration with the Royal Society, any considerable expenditure on space research seems likely to come from Defence Estimates.

Meanwhile, the Council for Scientific and Industrial Research has clearly gone some way further to provide the basis for a sound allocation of the national resources for research and development as between the different fields. If the Minister for Science can persuade the other research councils to analyse the distribution of their own efforts on similar lines, and promote co-operation and co-ordination of effort in the way the Council for Scientific and Industrial Research is now doing, any untoward duplication and waste of effort should be eliminated with increasing ease. More important, the Minister and the Advisory Council on Scientific Policy should be in a stronger position to resist any attempt to devote an unwise proportion of effort into specific fields on the more dubious ground of prestige rather than of genuine national interest and practical return.

\section{CAUSATION AND MODERN SCIENCE}

\section{Causality}

The Place of the Causal Principle in Modern Science. By Prof. Mario Bunge. Pp. xx +380 . (Cambridge, Mass. : Harvard University Press ; London : Oxford University Press, 1959.) 60s. net.

1 HIS is an unusual book by an unusual man in a most unusual position. The author is professor of theoretical physics and philosophy of science. The university that is guilty of this stupidity or bold initiative, whichever it may be, is Buenos Aires. The author is a target for real criticism, for he is not only thoroughly competent in his two fields and presents his work with great lucidity, but also he has a strong sense of relevance and balance. Despite the fame of the subject, it is unusual to find a book of this length devoted to this one topic written without wasting words. Though the work is far from epoch making, it is of an outstanding order of competence and value, indispensable not only to those who may wish to enlighten themselves on the subject, but even to specialists on the topic. Of those who have thought carefully and written about this subject, there must be few who have been aware of the great complexity and detailed considerations that they will find here. In short, the work does not transform our view of causation, but it sets out the whole matter in such balanced and detajled perspective that anyone who atternpts to discuss it without knowing this book may well be regarded as not having graduated in the subject.

The broad thesis may be put as follows. Few will require to be persuaded that not all laws and explana. tion in physics are causal; in fact, the pendulum has swung so far that many deny that the principle of causation has any role at all. Against this view, the author argues patiently and temperately to point out that causal laws and causal explanations do in fact exist, but he is emphatic that they are not the only kind; but he also holds that there are quite a number of non-causal types of law and explanation, and he describes these carefully. In short, his thesis is that the principle of causation takes an important role, though not a dominating one. It may be remarked that this may sound insipid, but if so, it is not insipid through compromise, but because, if the author is right, the world is governed by heterogeneous types of law. Another important part of the thesis is this. Certain thinkers, whom the author calls romantie, have denied that the causal relation connects one event with another event; and they have done so on what the author considers the correct grounds that every event is connected in innumerable ways with all sorts of other events and therefore that an event is not simply nicely and neatly connected with another one as, say, its cause. On the other hand, the romantics go on to deny that causation has any role because of the warp and weft in which events find themselves. This the author disputes, because it rests upon a misunderstanding of the nature of scientific laws, which, whether causal or not, deliberately abstract from the warp and weft and for scientific purposes isolate events satisfactorily.

The one main criticism to which this book would seem to be open is that it may fail to satisfy those who regard statistical laws as having superseded causal laws. Such critics would doubtless concede the existence of causal laws as described by the author, but insist that these should be reducible to statistical terms. It would be interesting to know whether they regard such a contention as a purely scientific one (in which case they would be refuted by the fact that science contains both types of law) or as a piece of philosophy of science (they would probably agree that it was the latter). Then the contention would seem really to concern the ultimate nature of scientific laws, and it is not easy to see what bearing this contention would have upon science itself. Further, it would be interesting to know how its exponents would set about proving the contention.

It would be valuable if crities would commit themselves on these points and if Prof. Bunge were to make a detailed reply. He would no doubt do so highly effectively.

J. O. WISDOM

\section{AUTOMATIC PROGRAMMING IN THE U.S.S.R.}

Programming Programme for the BESM Computer By A. P. Ershov. Translated from the Russian by M. Nadler. Edited by J. P. Cleave. Pp. vi +158. (London and New York: Pergamon Press, 1959.) 60s. net.

A UTOMATIC programming is aimed at allowing A us to present to a computer a statement of our problem in a form as close as possible to that in which we are used to expressing ourselves. This may be a mathematical form for the scientist or mathematician or perhaps 'technical English' for the business man.

The book under review describes Russian work along these lines based on a "symbolic or pseudomathematical" form. In my view this work is 